\title{
Molecular epidemiology of Pseudomonas aeruginosa isolated from lower respiratory tract of ICU patients
}

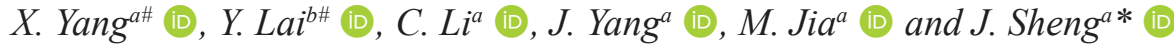

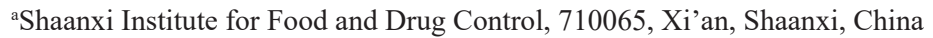

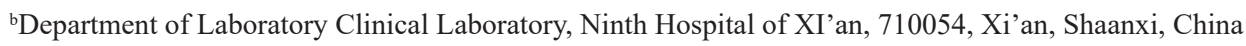 \\ ${ }^{\#}$ These two authors contribute to this work equally \\ *e-mail: JennieRiddledeg@yahoo.com
}

Received: July 18, 2019 - Accepted: December 20, 2019 - Distributed: May 31, 2021

(With 3 figures)

\begin{abstract}
Lower respiratory tract infections (LRTIs) caused by Pseudomonas aeruginosa are the most common infection among hospitalized patients, associated with increased levels of morbidity, mortality and attributable health care costs. Increased resistant Pseudomonas worldwide has been quite meaningful to patients, especially in intensive care unit (ICUs). Different species of Pseudomonas exhibit different genetic profile and varied drug resistance. The present study determines the molecular epidemiology through DNA fingerprinting method and drug resistance of $P$. aeruginosa isolated from patients with LTRIs admitted in ICU. A total of 79 P. aeruginosa isolated from patients with LRTIs admitted in ICU were characterized by Restriction Fragment Length Polymorphism (RFLP), Random Amplified Polymorphic DNA (RAPD) and Repetitive Extrapalindromic PCR (REP-PCR). Antibiotic resistance was determined by minimum inhibitory concentration (MIC) assay while MDR genes, viz, blaTEM, blaOXA, blaVIM, blaCTX-M-15 were detected by polymerase chain reaction (PCR). Of the 137 Pseudomonas sp isolated from ICU patients, 57.7\% of the isolates were reported to be $P$. aeruginosa. The overall prevalence of $P$. aeruginosa among the all included patients was $34.5 \%$. The RAPD analysis yielded 45 different patterns with 72 clusters with $57 \%$ to $100 \%$ similarity level. The RFLP analysis yielded 8 different patterns with 14 clusters with $76 \%$ to $100 \%$ similarity level. The REP PCR analysis yielded 37 different patterns with 65 clusters with 56\% to $100 \%$ similarity level. There was no correlation among the different DNA patterns observed between the three different methods. Predominant of the isolates (46.8\%) were resistant to amikacin. Of the 79 isolates, $60.8 \%$ were positive for blaTEM gene and $39.2 \%$ were positive for blaOXA gene. P. aeruginosa was predominantly isolated from patients with LRTIs admitted in ICU. The difference in the similarity level observed between the three DNA fingerprinting methods indicates that there is high inter-strain variability. The high genetic variability and resistance patterns indicates that we should continuously monitor the trend in the prevalence and antibiotic resistance of $P$. aeruginosa especially in patients with LRTIs admitted in ICU.
\end{abstract}

Keywords: Pseudomonas aeruginosa, lower respiratory tract infection, DNA typing, intensive care unit, RFLP, RAPD and REP-PCR markers.

\section{Epidemiologia molecular de Pseudomonas aeruginosa isolada em pacientes com infecções do trato respiratório inferior admitidos em UTI}

\section{Resumo}

Infecções do trato respiratório inferior (ITRIs) são as infecções mais comuns entre pacientes internados em unidade de terapia intensiva (UTI). Pseudomonas aeruginosa é a causa mais comum de ITRIs e está associada ao aumento da mortalidade. Diferentes espécies de Pseudomonas exibem diferentes perfis genéticos e resistência variada as drogas. O presente estudo determina a epidemiologia molecular através do método de fingerprinting de DNA e resistência as drogas de $P$. aeruginosa isoladas de pacientes com LTRIs internados em UTI. Um total de 79 P. aeruginosa isoladas de pacientes com ITRIs internados em UTI foram caracterizados por Polimorfismo de Comprimento de Fragmentos de Restrição (RFLP), DNA Polimórfico Amplificado ao Acaso (RAPD) e PCR Extrapalindrômico Repetitivo (REP-PCR). A resistência aos antibióticos foram determinadas pelos ensaios de concentrações inibitória mínima (MIC), enquanto os genes MDR, blaTEM, blaOXA, blaVIM, blaCTX-M-15 foram detectados pela reação em cadeia da polimerase (PCR). Das 137 Pseudomonas sp isoladas de pacientes de UTI, 57,7\% dos isolados foram relatados como P. aeruginosa. A prevalência geral de $P$. aeruginosa entre os pacientes incluídos foram de $34,5 \%$. A análise RAPD renderam 45 padrões diferentes com 72 clusters com nível de similaridade de $57 \%$ a $100 \%$. A análise RFLP renderam 8 padrões diferentes com 14 clusters com $76 \%$ a 100\% de similaridade. A análise de PCR do REP produziram 37 padrões 
diferentes com 65 clusters com nível de similaridade de 56\% a 100\%. Não houveram correlações entre os diferentes padrões de DNA observados entre os três diferentes métodos. Predominantes dos isolados $(46,8 \%)$ eram resistentes à amicacina. Dos 79 isolados, $60,8 \%$ foram positivos para o gene blaTEM e $39,2 \%$ foram positivos para o gene blaOXA. $P$. aeruginosa foi predominantemente isolado de pacientes com ITRIs internados em UTI. A diferença no nível de similaridade observado entre os três métodos de fingerprinting do DNA indica que há alta variabilidade inter-strain. A alta variabilidade genética e os padrões de resistência indicam que devemos monitorar continuamente a tendência na prevalência e resistência a antibióticos de $P$. aeruginosa, especialmente em pacientes com ITRIs internados em UTI.

Palavras-chave: Pseudomonas aeruginosa, infecção do trato respiratório inferior, DNA, unidade de terapia intensiva, marcadores RFLP, RAPD, REP-PCR.

\section{Introduction}

Lower respiratory tract infections (LRTIs) are the most common infection among patients admitted in intensive care unit (ICU) (Bhatta et al., 2019). Patients admitted in ICUs are highly susceptible to nosocomial infections due to prolonged hospitalization, decreased mobility and exposure to various medications (Sydnor and Perl, 2011). The incidence of nosocomial infections are higher among developing countries when compared to developed countries and it ranges from $2.3 \%$ to $49.2 \%$ across different clinical settings (Alberti et al., 2002). Pseudomonas sP. is the common cause of nosocomial infections and are highly associated with the LRTIs with increased mortality. The ICU is considered as established endemic settings favoring the growth of Pseudomonas sP. Its ability to colonize in-patients made it as highly critical organisms within ICUs settings (Erbay et al., 2003). Among Pseudomonas sp, P. aeuroginosa is considered as the most predominant species associated with severe LRTIs among patients admitted in ICUs and the second most common pathogen associated with ventilator-associated pneumonia (Weinstein et al., 2005; Sievert et al., 2013). According to the National Nosocomial Infection Surveillance System (NNISS) from China, P. aeruginosa was the predominant pathogen isolated from the lower respiratory tract, accounting for $12.8 \%, 12.3 \%$ and $13.4 \%$ during 2002-2004, 1999-2001 and 2005-2007, respectively (Ding et al., 2016; Wen et al., 2011). A multicenter cross sectional analysis from the United States reported $P$. aeuroginosa $(36.2 \%)$ as the most common Gram negative organisms isolated from patients with LRTIs acquired during ICU stay (Claeys et al., 2018).

$P$. aeruginosa with a high genetic variation is related to several infectious diseases. Due to its genetic diversity, the existing differences in the pathogenicity, and certain genotypes of $P$. aeruginosa were isolated from certain clinical settings. Understanding the relatedness and distribution of the pathogen is highly important to determine the epidemiology of $P$. aeruginosa infections and designing appropriate pathogen control measures (Nazik et al., 2007). Phenotypic methods including biotyping, serotyping, hemagglutination, cytotoxin activity assay, bacteriocin typing and immunoblotting were available. However, they lack reproducibility and the fact that $P$. aeruginosa is phenotypically unstable makes it difficult to rely on these methods for epidemiological studies. Genotypic methods are including pulse field gel electrophoresis, multiple-locus variable number tandem repeat analysis and multilocus sequence typing have high discriminatory power (Maatallah et al., 2013). However, they are require technical expertise, expensive, laborious and time-consuming. The PCR based molecular techniques gained importance in elucidating the epidemiology of $P$. aeruginosa. The restriction fragment length polymorphism (RFLP), randomly amplified polymorphic DNA (RAPD) and Repetitive Extrapalindromic PCR (REP-PCR) analyses have been developed for $P$. aeruginosa genotyping (Nanvazadeh et al., 2013; Joseph et al., 2010; Ratkai et al., 2010). These techniques are reported to be less laborious, rapid with high discriminatory power and could be employed in different clinical laboratory settings.

Anti-pseudomonal quinolone or an aminoglycoside along with $\beta$-lactams is considered as the primary treatment option for $P$. aeruginosa infections (Chinese Thoracic Society, 1999; Chinese Society of Critical Care, 2013). However, the treatment of $P$. aeruginosa infection is challenging due to increasing drug resistance. The increasing prevalence of multidrug resistant (MDR) strains is recognized as a global problem during the treatment of $P$. aeruginosa infections (Rossi Goncalves et al., 2017). The MDR P. aeruginosa strains are associated with increased morbidity and mortality, prolonging hospital stay and higher costs. The pan-drug resistance, the lack of effective antibiotics against MDR $P$. aeruginosa strains and continues the dissemination of such strains pose serious challenges in the infection control management (Murugan et al., 2018). Hence, understanding the epidemiology of pathogens and antibiotic resistance patterns of $P$. aeruginosa is highly warranted. The present study determined the prevalence, genetic heterogeneity and antibiotic resistance patterns of $P$. aeruginosa isolated from sputum samples of patients admitted with LRTIs in ICU by RFLP, RAPD, REP-PCR, drug resistance by MIC and resistance gene detection by PCR.

\section{Material and Methods}

\subsection{Sample collection}

A total of 229 samples (sputum-167, broncho alveolar lavage-62) were collected from patients with LRTIs adimitted in the ICU of Ninth Hospital of XI'an, Xi'an, Shaanxi, China between April 2017 and December 2018. From all patients or their legal representatives a written informed consent was obtained before collecting the samples. The hospital review board approval was obtained for the study. Samples were aseptically transported and processed immediately for microbiology analysis. 


\subsection{Isolation and identification of $P$. aeruginosa}

The samples were sub-cultured on to the MacConkey agar (HiMedia, India), incubated at $37^{\circ} \mathrm{C}$ for $18-24$ hours. Non-fermenting, irregular, green to brown color, catalase and oxidase positive colonies showing typical colony morphology of Pseudomonas $s$. were selected. The API ${ }^{\circledR}$ 20 NE microbial identification system for the non-fastidious, non-enteric gram negative bacilli (Biomerieux, USA) was used to identify the organisms. After identification, the isolates were sub-cultured on nutrient agar (HiMedia, India) and stored at $-40{ }^{\circ} \mathrm{C}$ in $20 \%$ glycerol containing nutrient broth until used for further analysis.

\subsection{DNA extraction}

DNA extraction was performed by boiling lysis method. Briefly, a loop full of overnight culture was suspended in $200 \mu \mathrm{L}$ of sterile water and boiled for 10 minutes at $95{ }^{\circ} \mathrm{C}$. Then the suspension was spin for 10 minutes at $14,000 \mathrm{~g}$ and supernatant was collected. The DNA present in the supernatant was quantified by spectrophotometry (NanoDrop ND-1000, USA) and stored at $-20^{\circ} \mathrm{C}$ until used.

\subsection{Randomly amplified polymorphic DNA}

RAPD was performed as described by Nanvazadeh et al. (2013). The PCR reaction mixture contains $12.5 \mu \mathrm{L}$ of ReadyMix $^{\text {TM }}$ Taq PCR Reaction Mix (Sigma-Aldrich, USA), $5 \mu \mathrm{L}$ of the template, $10 \mathrm{pm}$ of primer 3'-AGCGGGCCAA-5', and molecular grade PCR water to made up to $25 \mu \mathrm{L}$. The PCR was performed with the following cycling conditions: initial denaturation for 2 minutes at $96{ }^{\circ} \mathrm{C}$, followed by 3 cycles for 1 minute at $94{ }^{\circ} \mathrm{C}, 2$ minutes at $36{ }^{\circ} \mathrm{C}, 2$ minutes at $72{ }^{\circ} \mathrm{C}$. Then 29 cycles for 1 minute at $94{ }^{\circ} \mathrm{C}, 1$ minute at $58^{\circ} \mathrm{C}, 1$ minute at $72{ }^{\circ} \mathrm{C}$ and a final extension for 5 minutes at $72^{\circ} \mathrm{C}$. After PCR, DNA patterns resolved in $1.5 \%(\mathrm{w} / \mathrm{v})$ agarose gel were analyzed against $1 \mathrm{~Kb}$ DNA marker.

\subsection{Restriction fragment length polymorphism}

RFLP was performed as described by Joseph et al. (2010). A $50 \mu \mathrm{L}$ reaction mixture contains $5 \mu \mathrm{L}$ of the template, $10 \mathrm{pm}$ of each primer (forward: 5'- GACGGGTGAGTAATGCCTA -3' and reverse: 5' - CACTGGTGTTCCTTCCTATA -3 ') and $25 \mu \mathrm{L}$ of ReadyMix ${ }^{\mathrm{TM}}$ Taq PCR Reaction Mix (Sigma-Aldrich, USA). The PCR was performed with the following cycling conditions: initial denaturation for $2 \mathrm{~min}$ at $95^{\circ} \mathrm{C}$, followed by 30 cycles for $20 \mathrm{sec}$ at $94{ }^{\circ} \mathrm{C}$, $20 \mathrm{sec}$ at $54{ }^{\circ} \mathrm{C}, 40 \mathrm{sec}$ at $72{ }^{\circ} \mathrm{C}$ and a final extension for 1 minute at $72{ }^{\circ} \mathrm{C}$. Restriction digestions was performed with $10 \mu \mathrm{L}$ of the amplicons (expected size of $618 \mathrm{bp}$ ) by 2 U of HinfI (ThermoFisher Scientific, USA) restriction enzymes as per manufacturer's instruction for $16 \mathrm{~h}$ at $37^{\circ} \mathrm{C}$. DNA patterns resolved in $1.8 \%(\mathrm{w} / \mathrm{v})$ agarose gel were analyzed against $100 \mathrm{bp}$ DNA marker.

\subsection{Repetitive extrapalindromic PCR}

REP-PCR was performed as described by Sorkh et al. (2017). A $50 \mu \mathrm{L}$ reaction mixture contains $5 \mu \mathrm{L}$ of the template, 20 pm of each primer (forward: 5'- ICGICTTATCIGGCCTAC -3' and reverse: 5' - IIIICGICGICATCIGGC-3') and $25 \mu \mathrm{L}$ of ReadyMix ${ }^{\text {TM }}$ Taq PCR Reaction Mix (Sigma-Aldrich, USA). The PCR was performed with the following cycling conditions: initial denaturation for 2 minutes at $95{ }^{\circ} \mathrm{C}$, followed by 45 cycles for $30 \mathrm{sec}$ at $95^{\circ} \mathrm{C}, 1$ minute at $38^{\circ} \mathrm{C}$, 2 minutes at $72{ }^{\circ} \mathrm{C}$ and a final extension for 16 minutes at $72{ }^{\circ} \mathrm{C}$. DNA patterns resolved in $1.8 \%(\mathrm{w} / \mathrm{v})$ agarose gel were analyzed against $100 \mathrm{bp}$ DNA marker.

\subsection{Phylogenetic tree analysis}

DNA fingerprints obtained for RAPD, RFLP and REP-PCR, respectively, were analyzed separately for phylogenetic tree construction. They were coded to 1 or 0 binary forms, respectively. Using the NTSYSpc 2.11p software (Exeter Software, Setauket, USA) clustering (NJ-UPGMA method) was performed and phylogenetic tree was constructed.

\subsection{Minimum inhibitory concentration}

Minimum inhibitory concentration (MIC) of various antibiotics including gentamicin, amikacin, piperacillin-tazobactam, ciprofloxacin, cefepime, ceftazidime, imipenem and meropenem (Sigma-Aldrich, USA) against $P$. aeruginosa was determined. Innoculum was prepared by adjusting the overnight culture to $0.5 \mathrm{McF}$ arland's standard. The MIC assay was performed at a concentration of each antibiotics ranging from $0.03 \mu \mathrm{g} / \mathrm{mL}$ to $256 \mu \mathrm{g} / \mathrm{mL}$ by micro broth dilution method; using Muller-Hinton Broth (MHB, HiMedia, India) as described in Clinical Laboratory Standard Institute (CLSI, 2015) guidelines. Briefly, $10 \mu \mathrm{L}$ of culture was inoculated into MHB containing different concentration of antibiotics and incubated at $37{ }^{\circ} \mathrm{C}$ for $24 \mathrm{~h}$. The MIC was determined visually by the highest concentration showing the absence of growth.

\subsection{Resistant gene detection}

Antibiotic resistant genes including bla $_{T E M}$, bla $_{O X A}$, bla $a_{C T X-M-15}, b l a_{V I M}$ were detected through PCR as described earlier (Murugan et al., 2018). PCR was performed using ReadyMix $^{\text {TM }}$ Taq PCR Reaction Mix (Sigma-Aldrich, USA). Briefly, $25 \mu \mathrm{L}$ of ReadyMix ${ }^{\mathrm{TM}}, 5 \mu \mathrm{L}$ of template DNA, 5pmol of each primer described in Table 1, and molecular grade PCR water to make up to $50 \mu \mathrm{L}$ was used. Mastercycler ${ }^{\circledR}$ X50s (Eppendorf, Germany) was used for all PCR assays (RAPD, RFLP, REP-PCR). The PCR cycling conditions for resistant gene detection included: initial denaturation for $5 \mathrm{~min}$ at $94^{\circ} \mathrm{C}$ followed by 35 cycles for $30 \mathrm{sec}$ at $94{ }^{\circ} \mathrm{C}, 30 \mathrm{sec}$ at $56^{\circ} \mathrm{C}, 1.5 \mathrm{~min}$ at $72{ }^{\circ} \mathrm{C}$ and a final extension for $7 \mathrm{~min}$ at $72^{\circ} \mathrm{C}$. After PCR, amplicons were resolved in $1.2 \%$ agarose gel electrophoresis.

\subsection{Statistical analysis}

Mean and ranges were used to represent the continuous variables; number and percentages were used to represent categorical variable. Statistical significance $(P<.05$ was considered statistically significant) was determined through Chi-Square and ANOVA test using MINITAB statistical software (MINITAB version 13.1; MINITAB Inc, PA, USA). 
Table 1. Primer sequence of ESBL-MBL resistant genes.

\begin{tabular}{clc}
\hline Genes & \multicolumn{1}{c}{ Primer sequence (5'-3”) } & Amplicon size (bp) \\
\hline$b l a_{T E M}$ & Forward: TCAACATTTTCGTGTCGCCC & 766 \\
& Reverse: AACTACGATACGGGAGGGCT & 928 \\
$b l a_{O X A}$ & Forward: AGATCCTTGACCCGCAGTTG & \multirow{2}{*}{676} \\
$b l a_{C T X-M}$ & Reverse: CGCCGTCCCATCGAAAAATC & 456 \\
& Forward: AGACTGGGTGTGGCATTGAT & Reverse: TTAGGTTGAGGCTGGGTGAAGT \\
& Forward: TGTCCGTGATGGTGATGAGT & \\
\hline
\end{tabular}

Table 2. Characteristics of patient population.

\begin{tabular}{|c|c|c|}
\hline $\begin{array}{c}\text { Demographic } \\
\text { characteristics }\end{array}$ & $\begin{array}{c}\text { No of patients } \\
(\%)\end{array}$ & $P$ \\
\hline Mean age \pm SD (years)) & $43.3 \pm 5.3$ years & \\
\hline Male & $145(63.3 \%)^{*}$ & $<.05$ \\
\hline Female & $84(36.7 \%)$ & \\
\hline Smoker & $157(68.6 \%)^{*}$ & $<.05$ \\
\hline Non-smoker & $72(31.4 \%)$ & \\
\hline Bronchitis & $118(51.5 \%)^{*}$ & $<.05$ \\
\hline Pneumonia & $64(27.9 \%)$ & \\
\hline Lung abscess & $47(20.5 \%)$ & \\
\hline $\begin{array}{l}\text { Mechanical ventilator } \\
\text { support }\end{array}$ & $82(35.8 \%)$ & NA \\
\hline \multicolumn{3}{|l|}{ Male $(n=145)$} \\
\hline Smoker & $112(77.2 \%)^{*}$ & $<.05$ \\
\hline Non-smoker & $33(22.8 \%)$ & \\
\hline Bronchitis & $78(53.8 \%)^{*}$ & $<.05$ \\
\hline Pneumonia & $41(28.3 \%)$ & \\
\hline Lung abscess & $26(17.9 \%)$ & \\
\hline $\begin{array}{l}\text { Mechanical ventilator } \\
\text { support }\end{array}$ & $49(33.8 \%)$ & NA \\
\hline \multicolumn{3}{|l|}{ Female $(n=84)$} \\
\hline Smoker & $55(65.5 \%)^{*}$ & $<.05$ \\
\hline Non-smoker & $29(34.5 \%)$ & \\
\hline Bronchitis & $40(47.6 \%)$ & $>.05$ \\
\hline Pneumonia & $23(27.4 \%)$ & \\
\hline Lung abscess & $21(25.0 \%)$ & \\
\hline $\begin{array}{l}\text { Mechanical ventilator } \\
\text { support }\end{array}$ & $33(39.2 \%)$ & NA \\
\hline
\end{tabular}

*Significantly higher (Chi-Square test); $\mathrm{SD}=$ Standard Deviation, $\mathrm{P}=\mathrm{P}$ value of $<.05$ is considered as statistically significant, $\mathrm{NA}=$ Not applicable.

\section{Results}

\subsection{Patients and isolates}

Of the 229 patients, $145(63.3 \%)$ were male and $84(36.7 \%)$ were female (mean age $43.3 \pm 5.3$ years). Among these $157(68.6 \%)$ patients had the history of smoking and $82(35.8 \%)$ patients were under mechanical ventilator support. A detailed patient's characteristics are presented in Table 2. Of the 229 sputum samples, a total of 137 (59.8\%) samples isolated Pseudomonas sp.by culture method. All Pseudomonas sP. isolates were characterized using API ${ }^{\circledR}$ 20 NE microbial identification system (Biomerieux, USA).
Among the Pseudomonas sp., 79 (57.7\%) isolates were identified as $P$. aeruginosa. Of these, 47 (34.3\%) isolates were from male patients and $32(23.4 \%)$ were from female patients. The overall prevalence of $P$. aeruginosa among the all included patients was $34.5 \%$ (male $20.5 \%$; female, $14.0 \%)$. The presence of $P$. aeruginosa was significantly higher than other Pseudomonas sp $(P=.04)$. Among the 82 patients who were under mechanical ventilator support, $23(28 \%)$ patients isolated $P$. aeruginosa.

\subsection{Randomly amplified polymorphic DNA}

The RAPD-PCR revealed 45 different patterns with 1-10 different sized amplicons per strain with sizes ranging from $200->2700 \mathrm{bP}$. The phylogenetic analysis revealed 72 clusters with a similarity level ranging from $57-100 \%$. Seventeen (20.3\%) strains (strain numbers 1, 4, 11, 14, 17, $27,38,44,48,51,54,60,62,64,72,75$ ) showed $100 \%$ intra-strain similarity with 8 different clusters. Other strains revealed high variability (Figure 1).

\subsection{Restriction fragment length polymorphism}

The RFLP analysis revealed 8 different patterns (designated as genotype I to VIII) with 1-3 different sized amplicons per strain with sizes ranging from $180-618 \mathrm{bP}$. The phylogenetic revealed 14 clusters with a similarity level ranging from 49-100\%. Thirteen different clusters emerged with $100 \%$ intra-strain similarity of. Among these, 3 major restriction patterns were identified; 17 (21.5\%) strains (strain numbers 2, 8, 12, 14, 16, 18, 25, 28, 32, $44,47,50,56,59,74,75,77$ ) (genotype I) followed by $17(21.5 \%)$ strains (strain numbers 3, 6, 20, 23, 29, 30, 33, $42,48,51,54,63,66,68,69,72,78)$ with genotype II and $10(12.7 \%)$ strains (strain numbers 7, 13, 21, 31, 34, 35, $38,62,73,76)$ with genotype III. Other strains exhibited high heterogeneity (Figure 2).

\subsection{Repetitive extrapalindromic PCR}

The REP-PCR analysis revealed 37 different patterns with 1-17 different sized amplicons per strain with sizes ranging from $100-1,000 \mathrm{bP}$. The phylogenetic analysis of RAPD yielded 65 clusters at a similarity level ranging from 56-100\%. Eighteen (22.8\%) strains (strain numbers 3, 6, $18,19,21,25,37,42,44,45,49,51,53,64,66,68,69,79)$ showed $100 \%$ intra-strain similarity with 9 different clusters. Other strains revealed high variability, overall, the REP-PCR analysis revealed high heterogeneity among our isolates (Figure 3). 


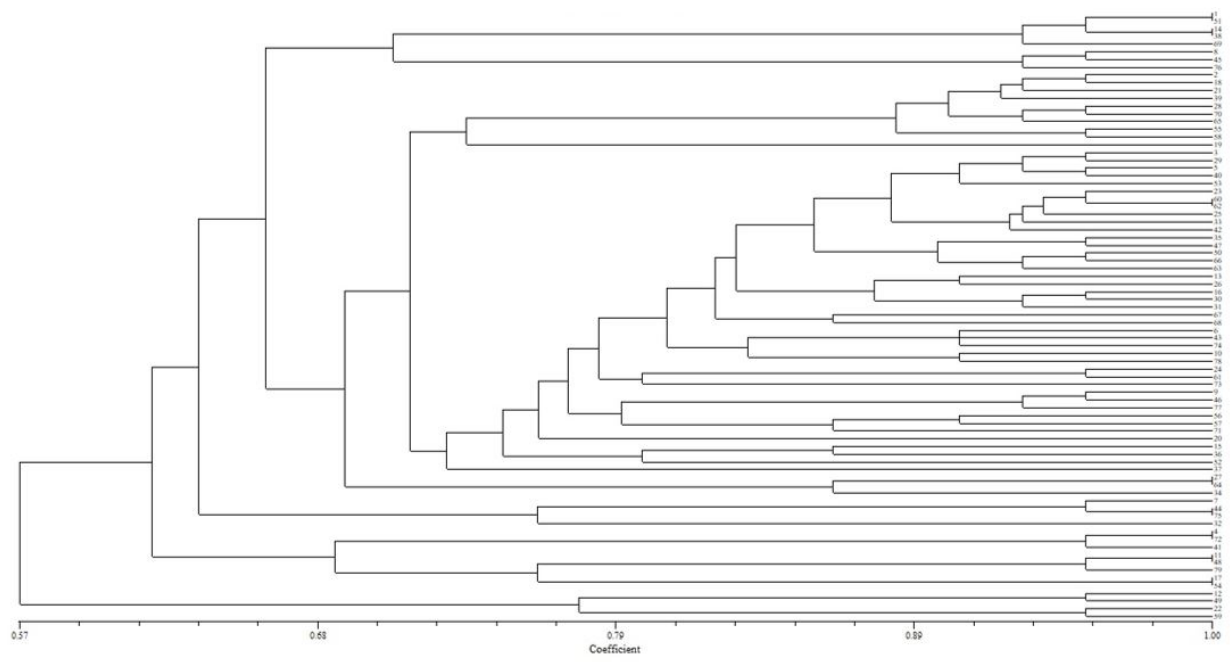

Figure 1. Phylogenetic tree analysis of RAPD.

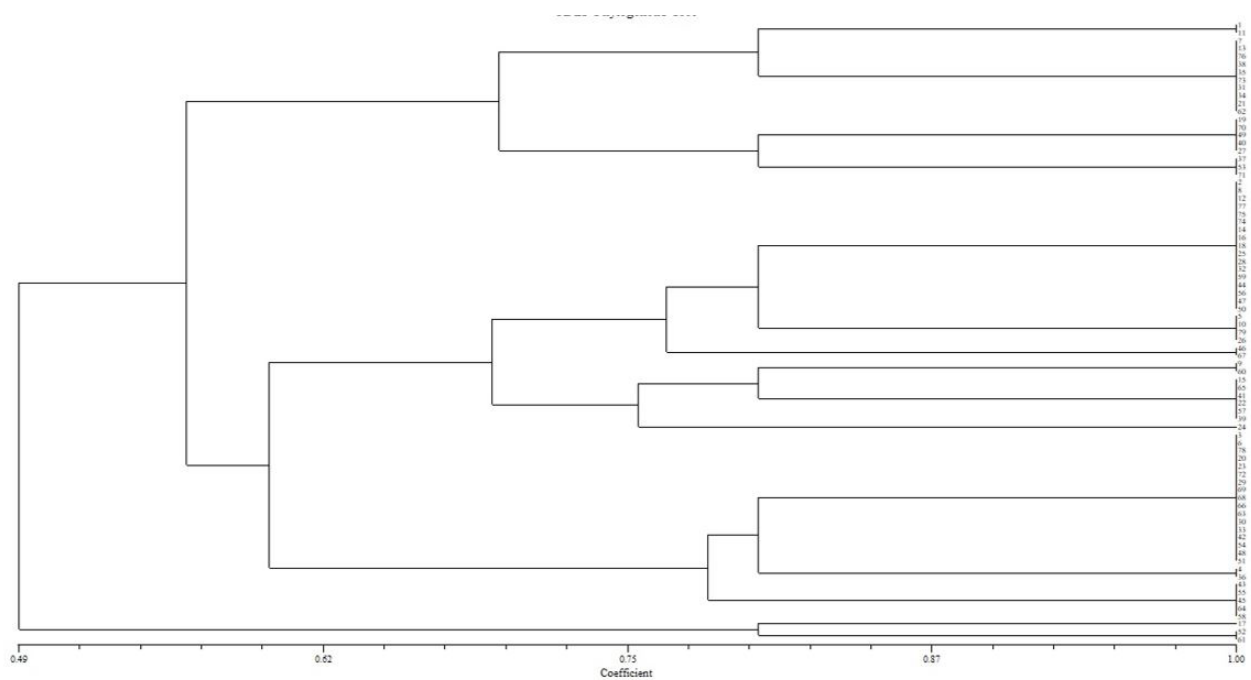

Figure 2. Phylogenetic tree analysis of RFLP.

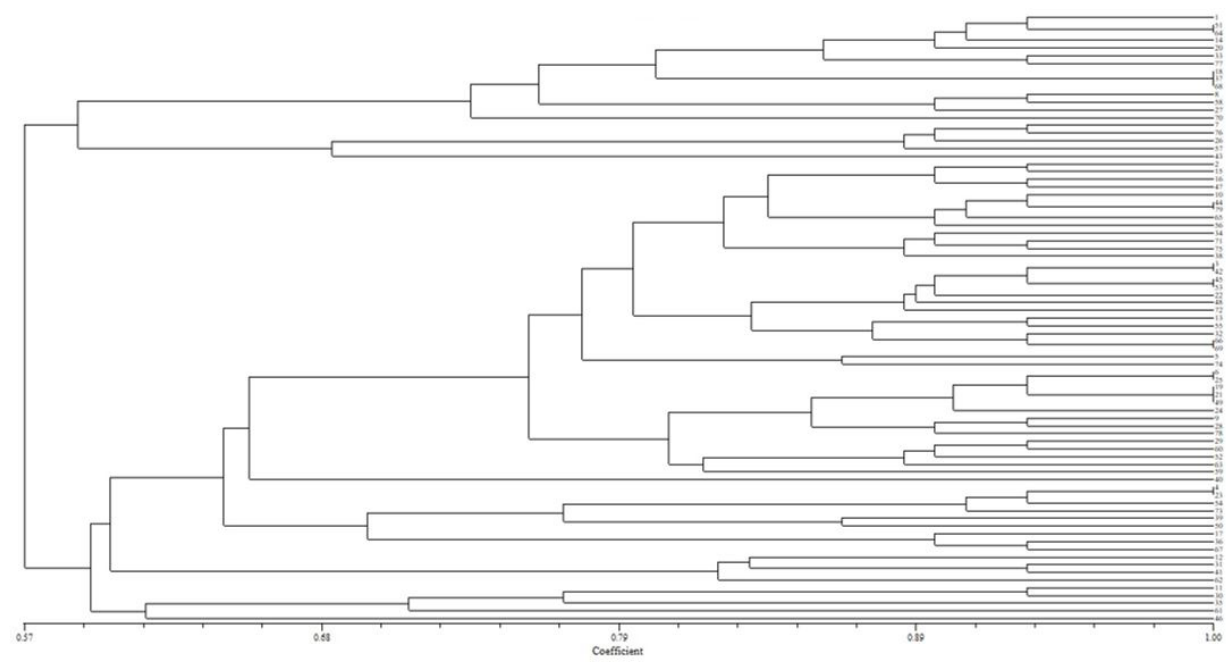

Figure 3. Phylogenetic tree analysis of REP-PCR. 
Table 3. Antibiotic resistance and MIC of $P$. aeruginosa isolates.

\begin{tabular}{|c|c|c|c|c|c|c|}
\hline \multirow{2}{*}{ Antibiotics } & \multicolumn{3}{|c|}{ No. of isolates $(n=79)$} & \multirow{2}{*}{$\begin{array}{c}\mathrm{MIC}_{50} \\
(\mu \mathrm{g} / \mathrm{mL})\end{array}$} & \multirow{2}{*}{$\begin{array}{c}\mathrm{MIC}_{90} \\
(\mu \mathrm{g} / \mathrm{mL})\end{array}$} & \multirow{2}{*}{$\begin{array}{c}\text { Range } \\
(\mu \mathrm{g} / \mathrm{mL})\end{array}$} \\
\hline & $\mathbf{S}$ & I & $\mathbf{R}$ & & & \\
\hline $\mathrm{AM}$ & $36(45.6 \%)$ & $6(7.6 \%)$ & $37(46.8 \%)$ & 2 & 64 & $0.06-128$ \\
\hline GN & $33(41.8 \%)$ & $12(15.2 \%)$ & $34(43 \%)$ & 4 & 32 & $0.5-64$ \\
\hline CIP & $44(55.7 \%)$ & $8(10.1 \%)$ & $27(34.2 \%)$ & 4 & 16 & $0.06-32$ \\
\hline CAZ & $53(67.1 \%)$ & $2(2.5 \%)$ & $24(30.4 \%)$ & 8 & 128 & $2-\geq 256$ \\
\hline MEM & $52(65.8 \%)$ & $4(5.1 \%)$ & $23(29.1 \%)$ & 4 & 32 & $0.5-64$ \\
\hline IPM & $42(53.2 \%)$ & $16(20.3 \%)$ & $21(26.5 \%)$ & 4 & 64 & $0.25-64$ \\
\hline CPM & $53(67.1 \%)$ & $8(10.1 \%)$ & $18(22.8 \%)$ & 16 & 64 & $\leq 0.03-\geq 356$ \\
\hline PTZ & $62(78.5 \%)$ & $3(3.8 \%)$ & $14(17.7 \%)$ & 1 & 32 & $8-128$ \\
\hline
\end{tabular}

$\mathrm{MIC}=$ Minimum Inhibitory Concentration; $\mathrm{S}=$ Sensitive; $\mathrm{I}=$ Intermediate Resistant; $\mathrm{R}=$ Resistant;Gentamicin (GN); amikacin (AM); piperacillin-tazobactam (PTZ); ciprofloxacin (CIP); cefepime (CPM); ceftazidime (CAZ); imipenem (IPM); and meropenem (MEM).

\subsection{Minimum inhibitory concentration}

Of the 79 P. aeruginosa isolates tested for antibiotic susceptibility, $37(46.8 \%)$ isolates were found to be resistant to amikacin, $34(43 \%)$ were resistant to gentamicin, $27(34.2 \%)$ were resistant to ciprofloxacin, 24 (30.4\%) were resistant to ceftazidime, 23 (29.1\%) were resistant to meropenem, $21(26.6 \%)$ were resistant to imipenem, $18(22.8 \%)$ were resistant to cefepime and $14(17.7 \%)$ isolates were resistant to piperacillin-tazobactam (Table 3). The antibiotic resistance pattern did not differ significantly among the isolates (ANOVA, $\mathrm{F}=0.00 ; P=1.00$ ).

\subsection{Resistant gene detection}

Of the 79 isolates, $48(60.8 \%)$ isolates amplified $b l a_{T E M}$ gene, $31(39.2 \%)$ isolates amplified bla $a_{O X A}$ gene, $21(26.6 \%)$ isolates amplified bla ${ }_{C T X-M}$ gene and $12(15.2 \%)$ isolates amplified $b l a_{V I M}$ gene. Significantly higher number of isolates amplified blaTEM gene when tested by PCR $(P<.05)$. All the resistant isolates amplified any of the four tested genes. Nine isolates which showed intermediate resistance towards the tested antibiotics, were positive for $\operatorname{bla}_{T E M}(5)$, bla $_{O X A}(2)$ and bla $a_{C T X-M}(2)$ genes.

\section{Discussion}

Lower respiratory tract infections are one of the important infectious diseases in developing countries and are often associated with high mortality (Agrawal and Kombade, 2014). Patients who are under ventilator support in the ICU settings are at high risk of having LRTIs with $P$. aeruginosa (Bobik and Siemiątkowski, 2014). The microbiological diagnosis of lower respiratory infection is often challenging due to possible contamination of the specimen by upper respiratory tract microorganisms (Ahmed et al., 2013). Thus, accurate diagnosis through the appropriate clinical specimen and appropriate techniques plays an important role. In this study, sputum and broncho alveolar lavage samples were aseptically collected and processed immediately. In our study, $57.7 \%$ of the Pseudomonas strains were identified as $P$. aeruginosa accounting up to $34.5 \%$ of the overall samples collected. Our study reported a higher $(34.5 \%)$ prevalence rate of $P$. aeruginosa than that reported from Nepal (13.9\%), Pakistan (24\%) and India $(26.8 \%)$ in patients with LRTIs (Bhatta et al., 2019; Fatima et al., 2012; Ahmed et al., 2013). The NNISS from China reported lower prevalence of $P$. aeruginosa ranging from 12.3-13.4\% during 1999-2007 in patients with LRTIs (Ding et al., 2016; Wen et al., 2011). A multicenter cross sectional analysis from the United States reported that $36.2 \%$ of the Gram negative organisms isolated from patients with LRTIs admitted in ICU were identified as $P$. aeruginosa, which is comparable $(34.5 \%)$ to that reported in our study (Claeys et al., 2018). While a study from Brazil, when compared to our results, reported a higher percentage (51.9\%) of $P$. aeruginosa isolates from ICU patients (Matos et al., 2016). Although the prevalence of $P$. aeruginosa varies in a different region, our study reported a higher rate compared to other studies from Asian countries including China. Thus, there is a need to continuously monitor the prevalence of $P$. aeruginosa especially in patients admitted in ICU with LRTIs in this region. Among the 79 patients who were isolated with P. aeruginosa, predominant $(52,65.8 \%)$ of them were from male patients. Similarly, a study from Pakistan reported that predominant (70.8\%) of the $P$. aeruginosa were isolated from male patients with LRTIs; the reported rate was slightly higher than our report (Fatima et al., 2012). In our study, $P$. aeruginosa infection was reported to be significantly higher in male patients $(P<.05)$. Our result indicates that $P$. aeruginosa isolated from patients admitted in ICU with lower respiratory infection showed varied prevalence rates and have epidemiological diversity, compared to other studies from different geographies.

Genetic complexity and the presence of large genome allows $P$. aeruginosa to thrive in different ecological conditions. Genomic heterogeneity forms the basis of several molecular techniques and is considered a valuable tool in epidemiological studies. Although several molecular techniques are available, PCR based molecular techniques, which are less laborious and cost-effective has gained importance in elucidating the epidemiology of P. aeruginosa. The RAPD, RFLP and REP-PCR are widely used in several epidemiological studies of $P$. aeruginosa (Nanvazadeh et al., 2013; Joseph et al., 2010; Ratkai et al., 
2010). The RAPD analysis in our study yielded 45 different patterns, RFLP yielded 8 different patterns and REP-PCR yielded 37 different patterns. A study from Iran, which included 50 P. aeruginosa from burn patients for RAPD, reported only 9 different genotypes which are lower than our report (Nanvazadeh et al., 2013). A study from Czech Republic which included 47 P. aeruginosa isolated from various clinical samples of patients admitted in ICU reported 22 different genotypes when analyzed by RAPD (Vaněrková et al., 2017). A study from Switzerland which included 55 (54-clinical, 4- environmental) $P$. aeruginosa isolated from burnt unit reported 8, 12 and 12 different patterns when digested the amplicons with BamHI, EcoRI and PstI, respectively (Blanc et al., 1993). A study from Iran, which analyzes $75 P$. aeruginosa isolated from burn patients by REP-PCR reported 40 different REP types, a comparable number of REP-PCR pattern was obtained from our study (Sorkh et al., 2017).Although we did not include different isolates from the same patients, we observed that $20.3 \%$ of our isolates showed $100 \%$ intra-strain similarity with 8 different clusters when analyzed by RAPD. The RFLP analysis revealed 13 different cluster with $100 \%$ intra-strain similarity. While in REP-PCR $22.8 \%$ of the isolates $100 \%$ intra-strain similarity with 9 different cluster. We found that 12 isolates had common patterns across three different techniques. Overall, all three methods revealed high heterogeneity among our isolates. However, RAPD and REP-PCR had good discriminatory power and yielded different patterns with high strain variability when compared to RFLP. Apart from the isolates, which showed $100 \%$ intra-strain similarity majority of our stains, yielded several different DNA fingerprints and showed high genetic variability. The genetic variation among our isolates suggests continues monitoring of genotypes with a geographical specific approach is required for effective identification of different types of $P$. aeruginosa strains.

The treatment of $P$. aeruginosa infection is often challenging due to its inherent resistance to a broad range of antibiotics, its ability to develop MDR and acquired resistance through chromosomal mutations (Gales et al., 2001; Zahraa et al., 2014). In our study, 46.8\% (MIC range $0.06-128 \mu \mathrm{g} / \mathrm{mL}$ ) of our isolates were found to be resistance to amikacin while only $43 \%$ (MIC range $0.5-64 \mu \mathrm{g} / \mathrm{mL}$ ) of isolates were found to be resistance to gentamicin. In contrast, a meta-analysis from China reported amikacin resistance in $22.5 \%$ of $P$. aeruginosa isolated from patients with VAP, which is lower than our result (Ding et al., 2016). While the study reported higher $(51.1 \%)$ gentamicin resistance (Ding et al., 2016). A study from Nepal that included 19 $P$. aeruginosa isolated from patients admitted in ICU with LRTIs reported higher resistance to cefepime (68.4\%), ciprofloxacin $(68.4 \%)$, amikacin $(52.6 \%)$, gentamicin $(52.6 \%)$ and lower resistance to imipenem (10.5\%) when compared to our results (Bhatta et al., 2019). Similarly, a study from Brazil reported higher rates of antibiotic resistance for meropenem (64.8\%), imipenem (64.8\%), ceftazidime $(63 \%)$, cefepime $(48.1 \%)$ and piperacillin/tazobactam (46.3\%) (Matos et al., 2016). While a study from Pakistan when compared to our results, reported lower resistance to amikacin (35\%), imipenem (24\%) and higher resistance to cefepime (40\%) among $P$. aeruginosa isolated from patients with LRTIs (Fatima et al., 2012). A study from India that included $P$. aeruginosa isolates from patients admitted in ICU with LRTIs reported varied results; the resistance rate of ceftazidime $(30.4 \%)$ and ciprofloxacin $(34.8 \%)$ corroborates with that reported in our study (Agrawal and Kombade, 2014). While resistance to imipenem (86.9\%), cefepime $(34.8 \%)$ was higher and gentamicin $(8.7 \%)$ was lower than our result (Agrawal and Kombade, 2014). A study from China that included $P$. aeruginosa from patients with VAP in intensive care units reported that $50 \%$ of their isolates showed resistance to ceftazidime and all (100\%) the isolates showed resistance to ciprofloxacin, which is much higher than our result (Xiao et al., 2013). In our study, the highest antibiotics resistance rate was observed for amikacin (46.8\%) while the lowest was observed for piperacillin-tazobactam (3.8\%).

Due to the stability against ESBLs, carbapenems (imipenem and meropenem) are considered as the most potent agents for MDR P. aeruginosa (Zavascki et al., 2010). In our study, meropenem and imipenem resistance were comparable, where $26.5 \%$ of our isolates were resistant to imipenem and $29.1 \%$ of isolates were resistant to meropenem. Our result on meropenem resistance (29.1\%) was slightly higher $(25 \%)$ than that reported from India (Murugan et al., 2018). A study from Brazil reported much higher rates of resistance $(64.8 \%)$ for meropenem and imipenem among $P$. aeruginosa isolated from ICU patients (Matos et al., 2016). Majority of our isolates found to be resistant to amikacin and gentamicin, however, there was no significant difference in resistance rates was found among the isolates $(P=1.00)$. In our study, $24(30.4 \%)$ of isolates were found to be MDR strains which were lower than that reported from Brazil (37\%) and Asia (42.8\%) (Chung et al., 2011; Matos et al., 2016). Of the 24 MDR isolates 9 (11.4\%) were isolated from patients who were under mechanical ventilator support. All our MDR isolates were found to be resistance to gentamicin which is in agreement with the findings of a study from Qatar (AbdulWahab et al., 2017).

The family of genes, TEM, SHV, CTX-M, PER, VEB, $G E S$, and $I B C$ encoding the ESBL enzymes was prevalent among P. aeruginosa (Rawat and Nair, 2010). Among several ESBL genes present, $b l a_{T E M}$ gene was predominantly carried by $P$. aeruginosa that confers resistance towards penicillin group of antibiotics (Dumas et al., 2006). In our study bla ${ }_{T E M}$ was predominant gene $(60.8 \%)$ present among our isolates. Our findings are in agreement with a study from India, which reported that bla $a_{T E M}$ was predominant gene present among the $P$. aeruginosa isolate, however, with higher rates $(72.5 \%)$ to that our result (Murugan et al., 2018). The study also reported that the presence of $b l a_{O X A}$ $(33.5 \%)$, bla $a_{V I M}(11.5 \%)$ and $b l a_{C T X-M}$ gene $(5 \%)$ genes were lower than our result (Murugan et al., 2018). In our study $26.6 \%$ of isolates were positive for $b l a_{O X A}$ gene, in contrast a study from Iraq reported that $93 \%$ of their isolates were positive of bla $a_{O X A}$ gene which was much 
higher than out report (Zahraa et al., 2014). The bla ${ }_{O X A}$ gene is considered as a naturally occurring gene, the high prevalence indicate a potential horizontal transfer in which Class D $\beta$-lactamases might get introduced by other co-inhabiting bacterial species (Girlich et al., 2004; Kong et al., 2005). We report that $15.2 \%$ of our isolates possessed bla ${ }_{V I M}$ gene lower $(1.6 \%)$ or absence of bla $a_{V I M}$ gene among their P. aeruginosa isolates (Fallah et al., 2013; Moosavian and Rahimzadeh, 2015; Amini and Mobasseri, 2017). When compared to the antibiotic resistance and the presence of resistance genes with the 3 different molecular typing, we did not find any specific patterns or genotypes associated with antibiotic resistance or resistance genes.

\section{Conclusion}

$P$. aeruginosa was the predominant isolate with an overall prevalence of $34.5 \%$ isolated from patients (male 20.5\%; female, $14.0 \%$ ) with LRTIs admitted in ICU. Majority of the isolates were resistant to amikacin and $b l a_{T E M}$ was the predominant gene detected among our isolates. The difference in the similarity level observed between the three DNA fingerprinting methods indicates that there is high inter-strain variability. The differences in resistance patterns emphasize the need for personalized antibiotic treatment. The high genetic variability and resistance patterns indicate that we should continuously monitor the trend in the prevalence and antibiotic resistance of $P$. aeruginosa especially in patients with LRTIs admitted in ICU.

\section{References}

ABDULWAHAB, A., ZAHRALDIN, K., SID AHMED, M.A., JARIR, S.A., MUNEER, M., MOHAMED, S.F., HAMID, J.M., HASSAN, A.A.I. and IBRAHIM, E.B., 2017. The emergence of multidrug-resistant Pseudomonas aeruginosa in cystic fibrosis patients on inhaled antibiotics. Lung India : Official Organ of Indian Chest Society, vol. 34, no. 6, pP. 527-531. http://dx.doi. org/10.4103/lungindia.lungindia_39_17. PMid:29098998.

AGRAWAL, G.N. and KOMBADE, S.P., 2014. Microbiological study of lower respiratory tract infections in ICU patients. International Journal of Current Microbiology and Applied Sciences, vol. 3, pP. 749-754.

AHMED, S.M., JAKRIBETTU, R.P., MELETATH, S.K., B, A. and VPA, S., 2013. Lower Respiratory Tract Infections (LTRIs): an insight into the prevalence and the antibiogram of the gram negative, respiratory, bacterial agents. Journal of Clinical and Diagnostic Research, vol. 7, no. 2, pP. 253-256. http://dx.doi. org/10.7860/JCDR/2013/5308.2740. PMid:23543819.

ALBERTI, C., BRUN-BUISSON, C., BURCHARDI, H., MARTIN, C., GOODMAN, S., ARTIGAS, A., SICIGNANO, A., PALAZZO, M., MORENO, R., BOULME, R., LEPAGE, E. and LE GALL, R., 2002. Epidemiology of sepsis and infection in ICU patients from an international multicentre cohort study. Intensive Care Medicine, vol. 28, no. 2, pP. 108-121. http://dx.doi.org/10.1007/ s00134-001-1143-z. PMid:11907653.

AMINI, K. and MOBASSERI, P., 2017. Detection rate of metallo$\beta$-lactamase-expressing genes; blaVIM-1, blaVIM-2 and blaSPM-1 in Pseudomonas aeruginosa isolates. International Journal of
Basic Science in Medicine, vol. 2, no. 1, pP. 41-45. http://dx.doi. org/10.15171/ijbsm.2017.09.

BHATTA, D.R., HAMAL, D., SHRESTHA, R., HS, S., JOSHI, P., NAYAK, N. and GOKHALE, S., 2019. Burden of multidrug resistant respiratory pathogens in intensive care units of tertiary care hospital. Asian Journal of Medical Sciences, vol. 10, no. 2, pP. 14-19. http://dx.doi.org/10.3126/ajms.v10i2.21098.

BLANC, D.S., SIEGRIST, H.H., SAHLI, R. and FRANCIOLI, P., 1993. Ribotyping of Pseudomonas aeruginosa: discriminatory power and usefulness as a tool for epidemiological studies. Journal of Clinical Microbiology, vol. 31, no. 1, pP. 71-77. http://dx.doi. org/10.1128/JCM.31.1.71-77.1993. PMid:8093252.

BOBIK, P. and SIEMIĄTKOWSKI, A., 2014. Ventilator-associated pneumonia and other infections. Pneumonologia i Alergologia Polska, vol. 82, no. 5, pP. 472-480. http://dx.doi.org/10.5603/ PiAP.2014.0062. PMid:25133817.

CHINESE SOCIETY OF CRITICAL CARE, 2013. Chinese Society of Critical Care Medicine. Chinese Journal of Integrative Medicine, vol. 52, pP. 524-543.

CHINESE THORACIC SOCIETY, 1999. Guidelines for the diagnosis and management of hospital acquired pneumonia. Chinese Journal of Tuberculosis and Respiratory Diseases, vol. 22, pP. 201-203.

CHUNG, D.R., SONG, J.H., KIM, S.H., THAMLIKITKUL, V., HUANG, S.G., WANG, H., SO, T.M., YASIN, R.M., HSUEH, P.R., CARLOS, C.C., HSU, L.Y., BUNTARAN, L., LALITHA, M.K., KIM, M.J., CHOI, J.Y., KIM, S.I., KO, K.S., KANG, C.I. and PECK, K.R., 2011. High prevalence of multidrug-resistant nonfermenters in hospital-acquired pneumonia in Asia. American Journal of Respiratory and Critical Care Medicine, vol. 184, no. 12, pP. 1409-1417. http://dx.doi.org/10.1164/rccm.2011020349OC. PMid:21920919.

CLAEYS, K.C., ZASOWSKI, E.J., TRINH, T.D., LAGNF, A.M., DAVIS, S.L. and RYBAK, M.J., 2018. Antimicrobial stewardship opportunities in critically ill patients with gram-negative lower respiratory tract infections: a multicenter cross-sectional analysis. Infectious Diseases and Therapy, vol. 7, no. 1, pP. 135-146. http://dx.doi.org/10.1007/s40121-017-0179-5. PMid:29164489.

CLINICALAND LABORATORY STANDARDS INSTITUTE CLSI, 2015. M100-S25: standards for antimicrobial susceptibility testing; twenty-fifth informational supplement an informational supplement for global application developed through the clinical and laboratory standards institute consensus. Wayne: CLSI.

DING, C., YANG, Z., WANG, J., LIU, X., CAO, Y., PAN, Y., HAN, L. and ZHAN, S., 2016. Prevalence of Pseudomonas aeruginosa and antimicrobial-resistant Pseudomonas aeruginosa in patients with pneumonia in mainland China: a systematic review and meta-analysis. International Journal of Infectious Diseases, vol. 49, pP. 119-128. http://dx.doi.org/10.1016/j.ijid.2016.06.014. PMid:27329135.

DUMAS, J.L., VAN DELDEN, C., PERRON, K. and KOHLER, T., 2006. Analysis of antibiotic resistance gene expression in Pseudomonas aeruginosa by quantitative real-time-PCR. FEMS Microbiology Letters, vol. 254, no. 2, pP. 217-225. http://dx.doi. org/10.1111/j.1574-6968.2005.00008.x. PMid:16445748.

ERBAY, H., YALCIN, A.N., SERIN, S., TURGUT, H., TOMATIR, E., CETIN, B. and ZENCIR, M., 2003. Nosocomial infections in intensive care unit in a Turkish university hospital: a 2-year survey. Intensive Care Medicine, vol. 29, no. 9, pP. 1482-1488. http://dx.doi.org/10.1007/s00134-003-1788-x. PMid:12898002. 
FALLAH, F., BORHAN, R.S. and HASHEMI, A., 2013. Detection of bla(IMP) and bla(VIM) metallo-beta-lactamases genes among Pseudomonas aeruginosa strains. International Journal of Burns and Trauma, vol. 3, no. 2, pP. 122-124. PMid:23638331.

FATIMA, A., NAQVI, S.B., KHALIQ, S.A., PERVEEN, S. and JABEEN, S., 2012. Antimicrobial susceptibility pattern of clinical isolates of Pseudomonas aeruginosa isolated from patients of lower respiratory tract infections. SpringerPlus, vol. 1, no. 1, pP. 70. http://dx.doi.org/10.1186/2193-1801-1-70. PMid:23397507.

GALES, A.C., JONES, R.N., TURNIDGE, J., RENNIE, R. and RAMPHAL, R., 2001. Characterization of Pseudomonas aeruginosa isolates: occurrence rates, antimicrobial susceptibility patterns, and molecular typing in the global SENTRY Antimicrobial Surveillance Program. 1997-1999. Clinical Infectious Diseases, vol. 32, suppl. 2, pP. S146-S155. http://dx.doi.org/10.1086/320186. PMid:11320454.

GIRLICH, D., NAAS, T. and NORDMANN, P., 2004. Biochemical characterization of the naturally occurring oxacillinase OXA50 of Pseudomonas aeruginosa. Antimicrobial Agents and Chemotherapy, vol. 48, no. 6, pP. 2043-2048. http://dx.doi. org/10.1128/AAC.48.6.2043-2048.2004. PMid:15155197.

JOSEPH, N.M., SISTLA, S., DUTTA, T.K., BADHE, A.S., RASITHA, D. and PARIJA, S.C., 2010. Role of intensive care unit environment and health-care workers in transmission of ventilator-associated pneumonia. Journal of Infection in Developing Countries, vol. 4, no. 5, pP. 282-291. http://dx.doi.org/10.3855/ jidc.800. PMid:20539060.

KONG, K.F., JAYAWARDENA, S.R., DEL PUERTO, A., WIEHLMANN, L., LAABS, U., TUMMLER, B. and MATHEE, K., 2005. Characterization of poxB, a chromosomal-encoded Pseudomonas aeruginosa oxacillinase. Gene, vol. 358, pP. 82-92. http://dx.doi.org/10.1016/j.gene.2005.05.027. PMid:16120476.

MAATALLAH, M., BAKHROUF, A., HABEEB, M.A., TURLEJROGACKA, A., IVERSEN, A., POURCEL, C., SIOUD, O. and GISKE, C.G., 2013. Four genotyping schemes for phylogenetic analysis of Pseudomonas aeruginosa: comparison of their congruence with multi-locus sequence typing. PLoS One, vol. 8, no. 12, pP. e82069. http://dx.doi.org/10.1371/journal.pone.0082069. PMid:24349186.

MATOS, E.C., MATOS, H.J., CONCEICAO, M.L., RODRIGUES, Y.C., CARNEIRO, I.C. and LIMA, K.V., 2016. Clinical and microbiological features of infections caused by Pseudomonas aeruginosa in patients hospitalized in intensive care units. Revista da Sociedade Brasileira de Medicina Tropical, vol. 49, no. 3, pP. 305-311. http://dx.doi.org/10.1590/0037-8682-0446-2015. PMid:27384827.

MOOSAVIAN, M. and RAHIMZADEH, M., 2015. Molecular detection of metallo-beta-lactamase genes, bla IMP-1, bla VIM-2 and bla SPM-1 in imipenem resistant Pseudomonas aeruginosa isolated from clinical specimens in teaching hospitals of Ahvaz, Iran. Iranian Journal of Microbiology, vol. 7, no. 1, pP. 2-6. PMid:26644866.

MURUGAN, N., MALATHI, J., THERESE, K.L. and MADHAVAN, H.N., 2018. Application of six multiplex PCRs among 200 clinical isolates of Pseudomonas aeruginosa for the detection of $20 \mathrm{drug}$ resistance encoding genes. The Kaohsiung Journal of Medical Sciences, vol. 34, no. 2, pP. 79-88. http://dx.doi.org/10.1016/j. kjms.2017.09.010. PMid:29413231.

NANVAZADEH, F., KHOSRAVI, A.D., ZOLFAGHARI, M.R. and PARHIZGARI, N., 2013. Genotyping of Pseudomonas aeruginosa strains isolated from burn patients by RAPD-PCR. Burns, vol. 39, no. 7, pP. 1409-1413. http://dx.doi.org/10.1016/j. burns.2013.03.008. PMid:23773789.

NAZIK, H., ONGEN, B., ERTURAN, Z. and SALCIOGLU, M., 2007. Genotype and antibiotic susceptibility patterns of Pseudomonas aeruginosa and Stenotrophomonas maltophilia isolated from cystic fibrosis patients. Japanese Journal of Infectious Diseases, vol. 60, no. 2-3, pP. 82-86. PMid:17515637.

RATKAI, C., PEIXE, L.V., GROSSO, F., FREITAS, A.R., ANTUNES, P., FODOR, E., HAJDU, E. and NAGY, E., 2010. Successful application of the DiversiLab repetitive-sequencebased PCR typing system for confirmation of the circulation of a multiresistant Pseudomonas aeruginosa clone in different hospital wards. Diagnostic Microbiology and Infectious Disease, vol. 67, no. 2, pP. 202-206. http://dx.doi.org/10.1016/j. diagmicrobio.2010.01.010. PMid:20338712.

RAWAT, D. and NAIR, D., 2010. Extended-spectrum betalactamases in gram negative bacteria. Journal of Global Infectious Diseases, vol. 2, no. 3, pP. 263-274. http://dx.doi.org/10.4103/0974777X.68531. PMid:20927289.

ROSSI GONÇALVES, I., DANTAS, R.C.C., FERREIRA, M.L., BATISTÃO, D.W.D.F., GONTIJO-FILHO, P.P. and RIBAS, R.M., 2017. Carbapenem-resistant Pseudomonas aeruginosa: association with virulence genes and biofilm formation. Brazilian Journal of Microbiology, vol. 48, no. 2, pP. 211-217. http://dx.doi. org/10.1016/j.bjm.2016.11.004. PMid:28034598.

SIEVERT, D.M., RICKS, P., EDWARDS, J.R., SCHNEIDER, A., PATEL, J., SRINIVASAN, A., KALLEN, A., LIMBAGO, B. and FRIDKIN, S., 2013. Antimicrobial-resistant pathogens associated with healthcare-associated infections: summary of data reported to the National Healthcare Safety Network at the Centers for Disease Control and Prevention, 2009-2010. Infection Control and Hospital Epidemiology, vol. 34, no. 1, pP. 1-14. http:// dx.doi.org/10.1086/668770. PMid:23221186.

SORKH, M., LEILI, S., NILOUFAR, R. and ELAHE, T., 2017. Molecular analysis of Pseudomonas aeruginosa strains isolated from burn patients by repetitive extragenic palindromic-PCR (Rep-PCR). Iranian Red Crescent Medical Journal, vol. 19, no. 4, pP. e43508. http://dx.doi.org/10.5812/ircmj.43508.

SYDNOR, E.R. and PERL, T.M., 2011. Hospital epidemiology and infection control in acute-care settings. Clinical Microbiology Reviews, vol. 24, no. 1, pP. 141-173. http://dx.doi.org/10.1128/ CMR.00027-10. PMid:21233510.

VANĚRKOVÁ, M., MALISOVA, B., KOTASKOVA, I., HOLA, V., RUZICKA, F. and FREIBERGER, T., 2017. Biofilm formation, antibiotic susceptibility and RAPD genotypes in Pseudomonas aeruginosa clinical strains isolated from single centre intensive care unit patients. Folia Microbiologica, vol. 62, no. 6, pP. 531-538. http://dx.doi.org/10.1007/s12223-017-0526-7. PMid:28365878.

WEINSTEIN, R.A., GAYNES, R. and EDWARDS, J.R., 2005. Overview of nosocomial infections caused by gram-negative bacilli. Clinical Infectious Diseases, vol. 41, no. 6, pP. 848-854. http://dx.doi.org/10.1086/432803. PMid:16107985.

WEN, X.M., REN, N., WU, A.H. and XU, X.H., 2011. Distribution of pathogens causing nosocomial infection monitored by national nosocomial infection surveillance system and changing trend. Zhongguo Yiyuan Ganranxue Zazhi, vol. 21, pP. 350-355.

XIAO, H., YE, X., LIU, Q. and LI, L., 2013. Antibiotic susceptibility and genotype patterns of Pseudomonas aeruginosa from mechanical ventilation-associated pneumonia in intensive care units. Biomedical Reports, vol. 1, no. 4, pP. 589-593. http:// dx.doi.org/10.3892/br.2013.94. PMid:24648991. 
Yang, X. et al.

ZAHRAA, M.J., MAYSAA, A.R.D., ABDUL, K.H.A. and SAFAA, M.J., 2014. Molecular identification and antibiotics resistance genes profile of Pseudomonas aeruginosa isolated from Iraqi patients. African Journal of Microbiological Research, vol. 8, no. 21, pP. 2183-2192. http://dx.doi.org/10.5897/AJMR2013.6472.
ZAVASCKI, A.P., CARVALHAES, C.G., PICAO, R.C. and GALES, A.C., 2010. Multidrug-resistant Pseudomonas aeruginosa and Acinetobacter baumannii: resistance mechanisms and implications for therapy. Expert Review of Anti-Infective Therapy, vol. 8, no. 1, pP. 71-93. http://dx.doi.org/10.1586/eri.09.108. PMid:20014903. 